\title{
Can Agroecological Transition Of Intensive Cereal System Of Indo-Gangetic Plains Deliver Sustainable And Nutritious Food?
}

\author{
M. K. Gora \\ CCS Haryana Agricultural University \\ Satish Kumar \\ CCS Haryana Agricultural University
}

H. S. Jat

ICAR-Central Soil Salinity Research Institute

S. K. Kakraliya

ICAR-Central Soil Salinity Research Institute

Madhu Choudhary

ICAR-Central Soil Salinity Research Institute

\section{A. K. Dhaka}

CCS Haryana Agricultural University

R. D. Jat

CCS Haryana Agricultural University

Manish Kakraliya

CCS Haryana Agricultural University

P. C. Sharma

ICAR-Central Soil Salinity Research Institute

M. L. Jat ( $\sim$ M.jat@cgiar.org )

NASC Complex

\section{Research Article}

Keywords: Conservation agriculture, Crop diversification, Crop productivity, Water productivity, Net returns, Nutritional values

Posted Date: March 7th, 2022

DOI: https://doi.org/10.21203/rs.3.rs-1369144/v1

License: @ (i) This work is licensed under a Creative Commons Attribution 4.0 International License. Read Full License 


\section{Abstract}

Indo-Gangetic plains (IGP) of South Asia have supported bulk of human and bovine population in the region since ages, and a spectacular progress has been made here on food production. However, this cereal-system-dominated region still suffers with challenges of malnourishment, declining total factor productivity and natural resource degradation with potential threats of climate change. Addressing these challenges would require a transition towards agroecological cropping systems. A study was, therefore, conducted on crop diversification and sustainable intensification options using agro-ecological approaches such as Conservation Agriculture (CA) to ensure food and nutritional security while sustaining the natural resources. On 2 years mean basis, CAbased cropping system management scenarios (mean of Sc2-Sc7) using diversified rotations; increased the system yield by $15.4 \%$, net return by $28.7 \%$, protein yield by $29.7 \%$ while using $53.0 \%$ less irrigation water compared to conventional tillage (CT)-based rice-wheat system (Sc1). Maize-mustard-mungbean on permanent beds (Sc4) recorded the highest productivity $(+40.7 \%)$, profitability $(+60.1 \%)$, and saved $81.8 \%$ of irrigation water compared to Sc1 (11.8 Mg ha $1 ; 2190$ USD ha $\left.^{-1} ; 2514 \mathrm{~mm} \mathrm{ha}^{-1}\right)$. It was closely followed by Sc5 $(32.3,57.4,413.8,75.5 \%)$ i.e. maize-wheat-mungbean on permanent beds. In terms of nutritional value, Sc5 was more balanced than other scenarios, and produced 43.8, 27.5 and $259.8 \%$ higher protein, carbohydrate and fat yields, respectively, compared to Sc1 $\left(0.93,8.55\right.$ and $\left.0.14 \mathrm{Mg} \mathrm{ha}^{-1}\right)$. Scenario 5 was able to meet the nutrient demand of 19,23 and 32 more persons ha $^{-1}$ year ${ }^{-1}$ with respect to protein, carbohydrate and fat demand, respectively, compared to Sc1 (44, 86 and 13 persons ha ${ }^{-1}$ year $\left.{ }^{-1}\right)$. However, the highest protein and fat yield and their adult equivalents was associated with Sc6 (soybean based) and Sc4 (maize based), respectively. Soybean based system (Sc6) was economically more efficient with respect to nutrients than other systems. Mungbean integration improved the system productivity by $17.2 \%$ and profitability by $32.1 \%$, while improving the irrigation water productivity by three times compared to CT-based systems. In western IGP, CA-based maize-wheat-mungbean system was the most productive, profitable and nutritionally rich and efficient system compared to other systems. Therefore, CA-based crop diversification is an option to ensure quality and nutritious food for the dwelling communities in the region.

\section{Introduction}

Sustainability of the intensive cereal (rice/wheat) production systems of South Asia has become a major concern owing to overexploitation of resources through continuous cultivation of monotonous rice-wheat (RW) system. It has resulted into more water extraction from groundwater aquifers, soil degradation by intensive tillage and imbalance fertilizer use and open field crop residue burning ${ }^{1-3}$. The problems are worsening in western Indo-Gangetic plains (IGP) where rice and wheat are cultivated with Government's investments for free electricity and highly subsidised nitrogen fertilizers, resulting in the depletion of groundwater aquifers and highly skewed use (towards nitrogen) of chemical fertilizers with low NUE. In India, among the cereals, rice and wheat are massively distributed through public distribution system (PDS) to the poor (below poverty line people, $>30 \%$ of total population) to ensure food security throughout the country. But, in recent years, the country has also been increasing the imports of legumes, oils and other nutrition food product. Pulses and oilseeds, the major sources of protein and oil, are essential for growth and development of human body. Increasing the production of major pulses and oilseeds are the Government's priority to fight against malnutrition by supplying it through PDS at nominal prices. Soil degradation, indiscriminate use of groundwater, injudicious use of fertilizer coupled with climate change effects, will make it increasingly difficult to produce sufficient amounts of food in future, while in present domestic per capita supply of some nutrient-rich foods such as legumes, oils and coarse grains has declined ${ }^{4,5}$.

The soil organic carbon (SOC) contents is less than $5 \mathrm{~g} / \mathrm{kg}$ compared with $15-20 \mathrm{~g} / \mathrm{kg}$ in uncultivated virgin soils ${ }^{6}$, owing to intensive tillage, removal/burning of crop residues, mining of soil fertility and intensive RW systems. This adds to the challenge of making farming more profitable, and sustainable for resilient production systems and future food security ${ }^{7}$. Moreover, there still exist large management yield gaps ranging from $14-47 \%, 18-70 \%$ and $36-77 \%$ in wheat, rice and maize, respectively. Its significant portion is due to water and nutrient management ${ }^{8}$. Conventional tillage (CT) based management practices for a longer period in RW system of IGP diminish the soil physical, chemical and biological properties because of the inappropriate management of water, nutrient and crop residues ${ }^{9,10}$.

Crop diversification with sustainable intensification has been recognized as an effective strategy for achieving the objectives of food and nutritional security, judicious use of land and water resources, and sustainable agricultural development ${ }^{11,12}$. Crop diversification, one of the major components of sustainable intensification in agriculture, helps in profit maximization through reaping the gains of complementary and supplementary relationships ${ }^{13}$. The necessity for crop diversification in IGP arises on account of (i) halting the fall in groundwater table, (ii) arresting the degradation of natural resources and the environment, (iii) attaining the self-reliance in pulses and oil to save foreign exchange, and (iv) to ensure food and nutritional security. Choudhary et al. ${ }^{1}$ highlighted that sustainability of crop production increases with increase in crop diversity that improves the nutrition diversity and climate change mitigations, and reduces inorganic fertilizer use in associations with legumes enhancing production or profitability ${ }^{14}$. Studies revealed the inefficiencies present in food production systems in terms of water and nutrient use, showing the possibility of integration of crops (oilseeds and pulses) with lower groundwater requirements and also enhancing calorie, fats and protein production ${ }^{15,16}$. Sustainable intensification of cereal systems may not only improve crop, water and nutrition productivity but also improve the soil and the environment health ${ }^{1,17,18}$.

Despite significant improvements in productivity under recent decades in cereal systems, rates of under nutrition remain high in South Asia, with adverse impacts on human, soil and environment. Therefore, RW systems need to be modified to decrease the impact of crop production on the environment, and for sustaining food and nutrition production ${ }^{19}$. Compatibility and sustainability of the natural resource in RW ecologies may be achieved by pursuing conservation agriculture (CA) based crop diversification with sustainable intensification, which are more friendly and efficient in utilizing natural resources. Presently, limited information is available on diversified cereal systems to ensure nutritional security while achieving the food security. Our aim is to evaluate the effect of different feasible diversified cropping systems on the productivity (crop and water), profitability and nutritional values of systems in the western IGP of South Asia. We hypothesized that CA-based management practices would improve the productivity and profitability while improving the nutritional quality by adopting diversified crops in RW system. 


\section{Results}

Weather. All the weather parameters measured during the study period are presented in Fig. 1. Crops received total rainfall of 1348 and $769 \mathrm{~mm}$ in $2018-19$ and 2019-20, respectively, although it was not distributed uniformly through the season and the year. During first year kharif season, mostly rainfall was received in June-263 mm, July- 549 mm, Aug- 125 mm and Sep- 311 mm, whereas in second year it was 18, 245, 101 and 13 mm, respectively. During rabi season, 80 and $307 \mathrm{~mm}$ rainfall was received during both consecutive years. The maximum and minimum temperature was almost same during both years.

Crops and system productivity. In current study, CA-based management practices significantly $(p \leq 0.05)$ influenced grain yields over the years (2018-2020) (Table 1). Rice yield was not significantly $(p \leq 0.05)$ influenced by the different rice based scenarios (Sc1-Sc3) in both the years. However, maize yield (rice equivalent; RE) in both the maize based scenarios (Sc4-Sc5) was significantly at par and higher by 36 and $46 \%$ (2-yr mean) than rice crop of Sc1. Soybean yield (RE) underSc5was similar to Sc1 but lower than maize based scenarios in both the years. In contrast, pigeon pea (Sc7) produced significantly ( $\leq \leq 0.05$ ) lower yields than all scenarios in both the years. In Sc7, the RE yield of pigeon pea was lower by 30 and $60 \%$ during first and second year, respectively compared to Sc1.

During first year, higher wheat yield was recorded with Sc2, Sc3 and Sc5 compared to other scenarios, whereas, in second year, almost similar wheat yield was recorded with all the wheat based scenarios except Sc1 and Sc4. The wheat yield under ZT flat system (Sc2 and Sc3) was 10.9\% (2-yr mean) higher than Sc1 (farmers' practice), however under permanent beds system (PBs; Sc5 to Sc7), it was only $3.5 \%$ higher. In the first year, higher wheat yield was recorded with flat system, whereas in second year it was reversed (Table 1). CA-based wheat equivalent yield of Sc4 (mustard on PB) was similar to CT-based scenario (Sc1) during both the years. CA-based mungbean scenarios produced $0.09,0.74,0.18,0.15$ and $0.69 \mathrm{Mg} \mathrm{ha}^{-1}$ (2-yr mean) additional mungbean yield under Sc3, Sc4, Sc5, Sc6 and Sc7, respectively, compared to Sc1 where mungbean crop was not taken (Table 1). Among the mungbean yield, Sc4 (maize based) produced the highest yield and Sc7 (pigeon pea based) closely followed it.

System yield (RE) varied from 11.06 to $17.24 \mathrm{Mg} \mathrm{ha}^{-1}$ during both the years of study (Table 1). Scenario 4 recorded higher yield over Sc1during first and second year, respectively, followed by Sc5. However, the lowest yield was recorded with Sc7 (11.95 Mg ha-1) as compared to Sc1. On 2 years mean basis, the highest RE yield was recorded with Sc4 followed by Sc5 compared to Sc1 (Table 1). On 2 years mean basis, system yield (RE) of CA-based scenarios (Sc2Sc7) was increased by 15\% i.e. $1.81 \mathrm{Mg} \mathrm{ha}^{-1}$ over the CT-based scenario (11.81 $\mathrm{Mg} \mathrm{ha}^{-1}$ ). The system yield under ZT flat system (Sc2 and Sc3) was $5.8 \%$ (2-yr mean) higher than Sc1 (farmers' practice), however under PBs (Sc4 to Sc7) it was improved by 20.1\%. CA-based, crop diversification of CT based ricewheat system with maize-wheat/mustard-mungbean increased the system yield by 37\% (2-yr mean). Rice (Sc2-Sc3) and maize (Sc4-Sc5) based systems recorded $\sim 6$ and 37\% (2-yr mean) higher system productivity. The contrast effects were significant to system productivity associated with different CA-based management practices (Table 3).

Economic profitability. The cultivation cost mainly attributed to field preparation, crop establishment, irrigation, fertilizer, pest management, harvesting/threshing, and man-days involved in crop production. The net return of rice, maize, soybean and pigeon pea varied from 809 to 1576 USD ha ${ }^{-}$

${ }^{1}$ infirst year and 400-2159 USD ha ${ }^{-1}$ during second year (Table 1). Scenario 5 increased the net returns by $124.2 \%$ followed by Sc4 (107.6\%) compared to Sc1 (833 USD ha $\left.{ }^{-1}\right)$. Whereas, the lowest (-27.4\% from Sc1) was recorded with pigeon pea crop in Sc7 (605 USD ha-1).Rice crop (Sc2-Sc3) recorded almost the similar net returns to farmers' practice, whereas maize crop increased the net return by $115.9 \%$.

The net returns in rabi season varied from 1320-1695 USD ha-1 during both the years (Table 3). The higher net returns were recorded with Sc2, Sc3 and Sc5 by $17.4,16.0$ and $13.6 \%$ compared to Sc1 (1357 USD ha-1), respectively. The wheat net returns under ZT flat system (Sc2 and Sc3) was 16.7\% (2-yr mean) higher than Sc1 (farmers' practice), however under PBs (Sc5 to Sc7) it was higher by $9.9 \%$ only. On 2 years mean basis, mungbean crop produced the net returns in order of Sc4 > Sc7 > Sc5 > Sc6. Whereas, the negative returns (-64 USD ha ${ }^{-1}$ ) were recorded under Sc3 (Table 1).

The system net returns varied from 1998 to 3735 USD ha $^{-1}$ under different management practices over the years (Table 1). Scenario 4 recorded the 37.6 and $86.9 \%$ net returns over Sc1 during first and second year, respectively, and it was closely followed by Sc5 (35.2 and $83.9 \%$ ). However, the lowest net returns was recorded with Sc3 as compared to Sc1. System net returns of CA-based scenarios (Sc2- Sc7) was increased by $28.7 \%$ (2-yr mean), and is equivalent to628 USD ha-1 over the CT-based scenario (2190 USD ha-1). The system yield under ZT flat system (Sc2 and Sc3) was 8.3\% (2-yr mean) higher than Sc1 (farmers' practice), however under PBs (Sc4 to Sc7) it was higher by $38.8 \%$. CA-based, crop 
Table 1

Grain yield and net return of crops and cropping systems affected by different management practices during 2018-19 and 2019-20

\begin{tabular}{|c|c|c|c|c|c|c|c|c|}
\hline \multirow[t]{2}{*}{ Scenarios $^{a}$} & \multicolumn{4}{|l|}{ Grain yield $\left(\mathrm{Mg} \mathrm{ha}^{-1}\right)$} & \multicolumn{4}{|l|}{ Net return (USD ha-1) } \\
\hline & $\begin{array}{l}\text { Rice/maize/ soybean/ } \\
\text { pigeon pea }\end{array}$ & $\begin{array}{l}\text { Wheat/ } \\
\text { mustard }\end{array}$ & $\begin{array}{l}\text { Mung } \\
\text { bean }\end{array}$ & System $^{b}$ & $\begin{array}{l}\text { Rice/maize/ soybean/ } \\
\text { pigeon pea }\end{array}$ & $\begin{array}{l}\text { Wheat/ } \\
\text { mustard }\end{array}$ & Mungbean & System \\
\hline \multicolumn{9}{|c|}{ Year 2018-19 } \\
\hline Sc1 & $5.73^{C}$ & $6.56^{\mathrm{AB}}$ & 0.00 & $12.55^{\mathrm{BC}}$ & $843^{D}$ & $1539^{A B}$ & 0.00 & $2382^{\mathrm{B}}$ \\
\hline $\mathrm{Sc} 2$ & $6.00^{\mathrm{BC}}$ & $7.03^{\mathrm{A}}$ & 0.00 & $13.31^{\mathrm{BC}}$ & $951^{C D}$ & $1666^{\mathrm{A}}$ & 0.00 & $2617^{B}$ \\
\hline Sc3 & $5.58^{\mathrm{C}}$ & $7.13^{\mathrm{A}}$ & 0.18 & $13.70^{\mathrm{B}}$ & $877^{D}$ & $1695^{\mathrm{A}}$ & 3 & $2575^{\mathrm{B}}$ \\
\hline Sc4 & $6.76^{\mathrm{AB}}(7.04)$ & $6.16^{\mathrm{BC}}(2.70)$ & 0.71 & $15.98^{A}$ & $1388^{\mathrm{AB}}$ & $1417^{\mathrm{BC}}$ & 472 & $3277^{A}$ \\
\hline Sc5 & $7.51^{\mathrm{A}}(7.82)$ & $6.75^{\mathrm{AB}}$ & 0.20 & $15.31^{A}$ & $1576^{\mathrm{A}}$ & $1595^{A}$ & 50 & $3221^{A}$ \\
\hline Sc6 & $5.51^{\mathrm{C}}(2.87)$ & $5.73^{C}$ & 0.17 & $12.15^{\mathrm{C}}$ & $1141^{\mathrm{BC}}$ & $1320^{C}$ & 24 & $2486^{B}$ \\
\hline Sc7 & $4.01^{\mathrm{D}}(1.25)$ & $5.80^{C}$ & 0.63 & $12.54^{\mathrm{BC}}$ & $809^{D}$ & $1343^{C}$ & 383 & $2535^{\mathrm{B}}$ \\
\hline \multicolumn{9}{|c|}{ Year 2019-20 } \\
\hline Sc1 & $5.95^{\mathrm{BC}}$ & $4.87^{\mathrm{B}}$ & 0.00 & $11.06^{\mathrm{D}}$ & $823^{C}$ & $1175 \mathrm{C}$ & 0.00 & $1998^{D}$ \\
\hline Sc2 & $5.77^{\mathrm{BC}}$ & $5.69^{A}$ & 0.00 & $11.75^{\mathrm{D}}$ & $756^{C}$ & $1520 A B$ & 0.00 & $2276^{C}$ \\
\hline Sc3 & $5.42^{\mathrm{C}}$ & $5.51^{\mathrm{A}}$ & 0.00 & $11.20^{\mathrm{D}}$ & $700^{C}$ & 1454B & -131 & $2023^{D}$ \\
\hline Sc4 & $9.16^{A}(9.55)$ & $4.81^{\mathrm{B}}(2.09)$ & 0.77 & $17.24^{\mathrm{A}}$ & $2071^{A}$ & $1122 \mathrm{C}$ & 542 & $3735^{A}$ \\
\hline Sc5 & $9.50^{A}(9.90)$ & $5.50^{\mathrm{A}}$ & 0.17 & $15.92^{B}$ & $2159^{A}$ & $1487 \mathrm{AB}$ & 30 & $3675^{A}$ \\
\hline Sc6 & $6.12^{\mathrm{B}}(3.03)$ & $5.98^{\mathrm{A}}$ & 0.14 & $12.93^{\mathrm{C}}$ & $1301^{B}$ & $1635 \mathrm{~A}$ & 9 & $2939^{B}$ \\
\hline Sc7 & $2.38^{\mathrm{D}}(0.75)$ & $5.73^{\mathrm{A}}$ & 0.75 & $11.35^{\mathrm{D}}$ & $400^{\mathrm{D}}$ & $1565 A B$ & 493 & $2457^{C}$ \\
\hline
\end{tabular}

${ }^{\text {a }}$ Refer Table 4 for description of scenarios

bystem grain yield was expressed as rice-equivalent yield $\left(\mathrm{Mg} \mathrm{ha}^{-1}\right)$

'Means followed by a similar uppercase letter within a column are not significantly different at 0.05 level of probability using Tukey's HSD test

${ }^{d}$ Values in parenthesis indicate the actual yield of crop

diversification of CT based rice-wheat system with maize-wheat/mustard-mungbean increased the system net return by $58.8 \%$ (2-yr mean).

Irrigation water use and water productivity. Different crops need variable amount of irrigation water to meet their evapotranspiration demand. The amount of irrigation water applied varied from 1336 to $2782 \mathrm{~mm} \mathrm{ha}^{-1}$ in rice, 109 to $281 \mathrm{~mm} \mathrm{ha}^{-1}$ in maize, $110-200 \mathrm{~mm} \mathrm{ha}^{-1}$ in soybean and $96-100 \mathrm{~mm}^{-1}$ in pigeon pea over the 2-years. The amount of water applied in CT-based rice crop (Sc1; farmers' practice) was significantly $(\mathrm{P}<0.05)$ higher by $~ 3,91,93$ and 95\% (2-years' mean) compared to CA-based rice (Sc2-Sc3), maize (Sc4-Sc5), soybean (Sc6) and pigeon pea (Sc7) scenarios, respectively (Fig. 2). However, diversified crops (maize, soybean and pigeon pea; Sc4-Sc7) saved 92\% of irrigation water compared to Sc1 (2114 mm ha ${ }^{-1}$ ) (2 years mean). The lowest irrigation water productivity $\left(\mathrm{WP}_{\mathrm{l}}\right)$ was recorded with rice and it ranged from $0.21-0.45 \mathrm{~kg}$ grain $\mathrm{m}^{-3}$. Highest $\mathrm{WP}_{\mathrm{I}}$ was observed with maize crop and it ranged from $3.49-6.99 \mathrm{~kg}_{\text {grain }} \mathrm{m}^{-3}$ across the years (Fig. 2). However, in soybean and pigeon pea, it was recorded from 1.51-2.61and 0.75-1.30 $\mathrm{kg}$ grain $\mathrm{m}^{-3}$.

Crop establishment influenced the water use significantly in wheat crop. The irrigation water use in wheat crop ranged from $146-555 \mathrm{~mm} \mathrm{ha}^{-1} \mathrm{across}$ the years, while in mustard (Sc4) it was 73-136 mm ha ${ }^{-1}$. The wheat irrigation water use under PBs (Sc5 to Sc7) was 27.5\% (2-yr mean) lower than Sc1 (farmers' practice), however under ZT flat system (Sc2 and Sc3)it was only 7.4\% lower (Fig. 2). CA-based scenarios (mean of Sc2 to Sc7) saved 29.4 and 26.6\%

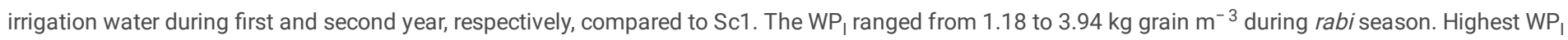
was recorded with Sc7 and Sc6 closely followed it during the study. CA-based scenarios (Sc2-Sc7) improved the WP, by 72 and $31 \%$ during first and second year, respectively, compared to Sc1. CA-based mungbean scenarios used 87.0, 161.4, 97.5, 109.2 and 138.0mm ha-1 (2-yr mean) additional irrigation water under Sc3, Sc4, Sc5, Sc6 and Sc7, respectively, compared to Sc1 where mungbean crop was taken (Fig. 2).

System irrigation water use varied from 391 to $3027 \mathrm{~mm} \mathrm{ha}^{-1}$ during both the years of study (Fig. 2). Scenario 4 recorded the 78.9 and $83.8 \%$ lower water use over Sc1 (2000 and $3027 \mathrm{~mm} \mathrm{ha}^{-1}$ ) during first and second year, respectively, and it was followed by Sc7 (69.1 and $87.1 \%$ ). On 2 years mean basis, the lowest water use was recorded with Sc4 (81.8\%) followed by Sc7 (79.9\%) compared to Sc1 (2514 mm ha $\left.{ }^{-1}\right)$. On 2 years mean basis, system irrigation water use of CA-based scenarios (Sc2- Sc7) was saved by 53\% i.e. $1339.5 \mathrm{~mm} \mathrm{ha}^{-1}$ over the CT-based scenario (2514 $\left.\mathrm{mm}^{-1}\right)$. The system irrigation water use under ZT flat system (Sc2 and Sc3) was 2.1\% (2-yr mean) lower than Sc1 (farmers' practice), however under PBs (Sc4 to Sc7) it was saved by $78.9 \%$ with different 


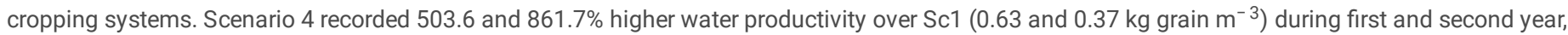
respectively, followed by Sc5 (276.8 and $649.3 \%$ ). On 2 years mean basis, CA-based management practises improved water productivity by 203.3 and $488.4 \%$ during first year and second year, respectively, as compared to farmers' practice (Sc1). CA-based, crop diversification of CT based rice-wheat system with maize-wheat/mustard-mungbean increased the system water productivity by 301\% (2-yr mean).

Protein yield. In present study, different crops and their management practices significantly $(p \leq 0.05)$ influenced the protein yields (Table 2). Sc6, Sc5 and Sc4improved the protein yield by $179.0,63.2$ and $50.0 \%$ in first year and 145.0, 80.0 and $97.5 \%$ in second year, respectively, compared to Sc1 (0.38 and $0.40 \mathrm{Mg}$ $\mathrm{ha}^{-1}$ ).However,Sc3 and Sc7 produced 3.8\% and 46.2\% lower protein yield than Sc1, respectively (Table 2). Based on 2-yr mean, Sc6 (soybean on PBs) was recorded the highest protein yields of $1.02 \mathrm{Mg} \mathrm{ha}^{-1}$ which was $161.5 \%$ higher than Sc1 $\left(0.39 \mathrm{Mg} \mathrm{ha}{ }^{-1}\right)$. Linear contrast effects were significant to protein yield of CT and CA-based scenarios in both the years (Table 3).

The protein yield varied from $0.44-0.69 \mathrm{Mg} \mathrm{ha}^{-1}$ in wheat crop and $0.39-0.52$ in mustard crop during both the years (Table 2). On 2 years mean basis, $16.0 \%$ higher protein yield was recorded with Sc5, closely followed by Sc3 (13.2\%) compared to Sc1 (0.53 Mg ha-1). CT (Sc1) vs CA based scenarios (mean of Sc2Sc7) contrast effect was not significant on wheat protein yield in 2018-19, but it was significant to 2019-20. CA-based mungbean scenarios produced 0.02, 0.18, 0.05, 0.04 and $0.17 \mathrm{Mg} \mathrm{ha}^{-1}$ additional protein yield from mungbean under Sc3, Sc4, Sc5, Sc6 and Sc7, respectively, compared to Sc1 (0.0 Mg ha- ${ }^{-1}$ ). Among the mungbean scenarios, Sc4 (mungbean on PBs) produced the highest protein yield compared to other mungbean scenarios (mean of 2 years).

System protein yield varied from 0.84 to $1.66 \mathrm{Mg} \mathrm{ha}^{-1}$ during both the years of study (Table 2). Scenario 6 recorded the 64.4 and $85.7 \%$ higher protein yield over Sc1 (1.01 and $0.84 \mathrm{Mg} \mathrm{ha}^{-1}$ ) during first and second year, respectively, followed by Sc5 (33.7 and 56.0\%). However, the lowest (0.93 $\mathrm{Mg}^{-1}$ ) protein yield was recorded with Sc1. On 2 years mean basis, Sc6 and Sc5 recorded 74.1 and $43.9 \%$ higher protein yields over Sc1 (0.93 Mg ha- $\left.{ }^{-1}\right)$. The percent increment of protein yields over Sc1 was in order of Sc6 > Sc5 > Sc4 > Sc2 > Sc3 > Sc7 on 2 years mean basis (Table 2). System protein yield (2-yr mean) of CAbased scenarios (Sc2-Sc7) improved 29.7\% compared to Sc1. The protein yield under ZT flat system (Sc2 and Sc3) was 7.3\% (2-yr mean) higher than Sc1 (farmers' practice), however under PBs (Sc4 to Sc7) higher by $41.0 \%$. The contrast effects were significant to system protein productivity associated with different CA-based management practices (Table 3).

Carbohydrate yield. Crops and their management practices significantly $(p \leq 0.05)$ influenced the carbohydrate yield. In the first year, higher carbohydrate yield was recorded with Sc2, Sc4 and Sc5, whereas in second year it was recorded with Sc4 and Sc5 (Table 2). However, other scenarios i.e. Sc3, Sc6 and Sc7 produced the lower carbohydrate yield compared to Sc1 during both years. Maize crop produced the higher carbohydrate yield of 33.0 and $42.5 \%$ inSc4 and Sc5compared to Sc1 (4.59 Mg ha ${ }^{-1}$ ). However, soybean and pigeon pea produced 78.1 and 85.5\% lower carbohydrate yield than Sc1, respectively (Table 2). Contrast effects (CT vs CA) were significant to carbohydrate under different scenarios and combinations of management practices (Table 3).

The carbohydrate yield under wheat crop varied from 3.33-5.01 $\mathrm{Mg} \mathrm{ha}^{-1}$ during both the years (Table 2). Carbohydrate yield (2-yr mean) improved by 11.9 and $11.1 \%$ in Sc2 and 
Table 2

Protein, carbohydras and fat yield of different crops and cropping systems as affected by different management practices during the year 2018-19 and :

\begin{tabular}{|c|c|c|c|c|c|c|c|c|c|c|c|}
\hline \multirow[t]{2}{*}{ Scenarios $^{a}$} & \multicolumn{4}{|c|}{ Protein yield $\left(\mathrm{Mg} \mathrm{ha}^{-1}\right)$} & \multicolumn{4}{|c|}{ Carbohydras yield $\left(\mathrm{Mg} \mathrm{ha}^{-1}\right)$} & \multicolumn{3}{|c|}{ Fat yield $\left(\mathrm{Mg} \mathrm{ha}^{-1}\right)$} \\
\hline & $\begin{array}{l}\text { Rice/maize/ } \\
\text { soybean/ } \\
\text { pigeon pea }\end{array}$ & $\begin{array}{l}\text { Wheat/ } \\
\text { mustard }\end{array}$ & Mungbean & System & $\begin{array}{l}\text { Rice/maize/ } \\
\text { soybean/ } \\
\text { pigeon pea }\end{array}$ & $\begin{array}{l}\text { Wheat/ } \\
\text { mustard }\end{array}$ & Mungbean & System & $\begin{array}{l}\text { Rice/maize/ } \\
\text { soybean/ } \\
\text { pigeon pea }\end{array}$ & $\begin{array}{l}\text { Wheat/ } \\
\text { mustard }\end{array}$ & Mungbec \\
\hline \multicolumn{12}{|c|}{ Year 2018-19 } \\
\hline Sc1 & $0.38^{C}$ & $0.62^{\mathrm{BC}}$ & 0.00 & $1.01^{\mathrm{D}}$ & $4.50^{\mathrm{BC}}$ & $4.59^{\mathrm{B}}$ & 0.00 & $9.09^{B}$ & $0.03^{C}$ & $0.11^{\mathrm{B}}$ & 0.00 \\
\hline Sc2 & $0.40^{\mathrm{C}}$ & $0.67^{A B}$ & 0.00 & $1.08^{\mathrm{CD}}$ & $4.72^{\mathrm{BC}}$ & $4.93^{\mathrm{AB}}$ & 0.00 & $9.66^{\mathrm{B}}$ & $0.04^{C}$ & $0.11^{\mathrm{B}}$ & 0.00 \\
\hline Sc3 & $0.38^{C}$ & $0.69^{A}$ & 0.04 & $1.11^{\mathrm{C}}$ & $4.36^{\mathrm{C}}$ & $5.01^{\mathrm{A}}$ & 0.11 & $9.49^{\mathrm{B}}$ & $0.03^{C}$ & $0.10^{\mathrm{B}}$ & 0.00 \\
\hline Sc4 & $0.57^{\mathrm{B}}$ & $0.52^{\mathrm{D}}$ & 0.17 & $1.25^{\mathrm{B}}$ & $5.11^{\mathrm{AB}}$ & $0.77^{\mathrm{D}}$ & 0.44 & $6.32^{C}$ & $0.30^{\mathrm{B}}$ & $1.06^{\mathrm{A}}$ & 0.01 \\
\hline Sc5 & $0.62^{\mathrm{B}}$ & $0.68^{A B}$ & 0.05 & $1.35^{\mathrm{B}}$ & $5.74^{\mathrm{A}}$ & $4.72^{\mathrm{AB}}$ & 0.12 & $10.58^{\mathrm{A}}$ & $0.34^{\mathrm{B}}$ & $0.12^{\mathrm{B}}$ & 0.00 \\
\hline Sc6 & $1.06^{\mathrm{A}}$ & $0.57^{\mathrm{CD}}$ & 0.04 & $1.66^{\mathrm{A}}$ & $0.97^{\mathrm{D}}$ & $3.96^{\mathrm{C}}$ & 0.11 & $5.04^{\mathrm{D}}$ & $0.56^{\mathrm{A}}$ & $0.12^{\mathrm{B}}$ & 0.00 \\
\hline Sc7 & $0.26^{\mathrm{D}}$ & $0.61^{\mathrm{C}}$ & 0.15 & $1.02^{\mathrm{CD}}$ & $0.83^{\mathrm{D}}$ & $4.01^{\mathrm{C}}$ & 0.40 & $5.24^{\mathrm{D}}$ & $0.02^{\mathrm{C}}$ & $0.12^{\mathrm{B}}$ & 0.01 \\
\hline \multicolumn{12}{|c|}{ Year 2019-20 } \\
\hline Sc1 & $0.40^{\mathrm{C}}$ & $0.44^{\mathrm{C}}$ & 0.00 & $0.84^{\mathrm{C}}$ & $4.67^{\mathrm{B}}$ & $3.33^{\mathrm{B}}$ & -0.00 & $8.01^{\mathrm{B}}$ & $0.04^{\mathrm{D}}$ & $0.09^{B}$ & 0.00 \\
\hline Sc2 & $0.39^{C}$ & $0.52^{\mathrm{AB}}$ & 0.00 & $0.91^{\mathrm{C}}$ & $4.51^{\mathrm{B}}$ & $3.93^{\mathrm{A}}$ & -0.00 & $8.44^{\mathrm{B}}$ & $0.04^{\mathrm{D}}$ & $0.10^{\mathrm{B}}$ & 0.00 \\
\hline Sc3 & $0.37^{C}$ & $0.51^{\mathrm{B}}$ & 0.00 & $0.87^{C}$ & $4.22^{\mathrm{B}}$ & $3.79^{A}$ & -0.00 & $8.02^{\mathrm{B}}$ & $0.03^{\mathrm{D}}$ & $0.09^{B}$ & 0.00 \\
\hline Sc4 & $0.79^{\mathrm{B}}$ & $0.39^{C}$ & 0.19 & $1.36^{\mathrm{B}}$ & $7.09^{A}$ & $0.58^{C}$ & 0.48 & $8.16^{\mathrm{B}}$ & $0.38^{C}$ & $0.82^{A}$ & 0.01 \\
\hline Sc5 & $0.72^{\mathrm{B}}$ & $0.55^{\mathrm{AB}}$ & 0.04 & $1.31^{\mathrm{B}}$ & $7.33^{\mathrm{A}}$ & $3.80^{\mathrm{A}}$ & 0.10 & $11.23^{\mathrm{A}}$ & $0.43^{\mathrm{B}}$ & $0.09^{B}$ & 0.00 \\
\hline Sc6 & $0.98^{\mathrm{A}}$ & $0.55^{\mathrm{AB}}$ & 0.03 & $1.56^{\mathrm{A}}$ & $1.04^{C}$ & $4.14^{\mathrm{A}}$ & 0.08 & $5.26^{C}$ & $0.58^{\mathrm{A}}$ & $0.09^{B}$ & 0.00 \\
\hline Sc7 & $0.16^{\mathrm{D}}$ & $0.58^{\mathrm{A}}$ & 0.18 & $0.92^{C}$ & $0.50^{\mathrm{D}}$ & $3.94^{\mathrm{A}}$ & $0.47^{A}$ & $4.91^{\mathrm{C}}$ & $0.01^{\mathrm{D}}$ & $0.10^{\mathrm{B}}$ & 0.01 \\
\hline
\end{tabular}

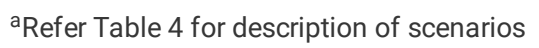

bMeans followed by a similar uppercase letter within a column are not significantly different at 0.05 level of probability using Tukey's HSD test.

Sc3, respectively compared to Sc1 (3.96 $\left.\mathrm{Mg} \mathrm{ha}^{-1}\right)$. Contrast effects were significant to carbohydrate yield in first year and non-significant in second year. CAbased mungbean scenarios produced 0.05, 0.46, 0.11, 0.10 and 0.44 Mg ha ${ }^{-1}$ (2-yr mean) additional carbohydrate yield under Sc3, Sc4, Sc5, Sc6 and Sc7, respectively, compared to farmers' practice $\left(0.0 \mathrm{Mg} \mathrm{ha}^{-1}\right)$. Among the mungbean scenarios, CA-based Sc4and Sc7 produced higher carbohydrate yield compared to other mungbean scenarios.

System carbohydrate yield varied from $4.91-11.23 \mathrm{Mg} \mathrm{ha}^{-1}$ during both the years (Table 2). Sc5 recorded the highest carbohydrate yield of $16.4 \%$ and $40.2 \%$ over Sc1 (9.09 and $8.01 \mathrm{Mg} \mathrm{ha}^{-1}$ ) during first and second year, respectively, followed by Sc2 (6.3 and 5.4\%) and Sc3 (4.4 and 0.1\%). However, the lowest (5.1 $\mathrm{Mg} \mathrm{ha}^{-1}$ ) carbohydrate yield was recorded with Sc7 (pigeon pea based system). On 2 years mean basis, Sc5, Sc2 and Sc3 recorded 27.5, 5.8 and $2.4 \%$ higher carbohydrate yields over Sc1 (8.6 Mg ha- $\left.{ }^{-1}\right)$. Contrast effects (CT vs CA) were significant to system carbohydrate yield in first year and non-significant in second year (Table 3).

Fat yield. Fat yield under different scenarios in 2 years varied from 0.01 to $0.58 \mathrm{Mg} \mathrm{ha}^{-1}$ (Table 2). The fat yield was higher by 1528.6 and $1000 \%$ (2-yr mean) with Sc6 and Sc5, respectively, compared to Sc1 (0.035 Mg ha-1). Fat yield was 871.4 and $14.3 \%$ higher with Sc4 and Sc2, respectively, as compared to Sc1. In both the years, contrast effects were significant to fat yield associated with different CA-based management practices (Table 3).

No appreciable change in fat yield was recorded under wheat crop, however, mustard crop produced the 863.6 and $811.1 \%$ higher fat yield in first and second years compared to Sc1 (wheat crop), respectively. In both the years, contrast effects were significant to system fat yield associated with different CA-based management practices (Table 3). Among the mungbean scenarios, CA-based Sc4 and Sc7 produced a little fat yield compared to other mungbean scenarios (Table 2).

System fat yield varied from 0.12 to $1.37 \mathrm{Mg} \mathrm{ha}^{-1}$ during both the years (Table 2). On 2 years mean basis, Sc4, Sc6 and Sc5 recorded $821.4,382.1$ and $253.6 \%$ higher fat yields over Sc1 $\left(0.14 \mathrm{Mg} \mathrm{ha}^{-1}\right)$. Compared to CT-based RW system, fat yield was lower by $\sim 7.0 \%$ in both Sc3 and Sc7. The contrast effects were significant to system fat yield associated with different CA-based management practices (Table 3 ).

Systems nutritional efficiency. On protein demand equivalent basis, CA-based scenarios could meet out the adult protein demand of 56.7 persons ha ${ }^{-1}$ year ${ }^{-1}$ compared to 44 person's ha ${ }^{-1}$ year $^{-1}$ (2-yr mean) with CT-based system (Sc1). Sc6, Sc5 and Sc4 could meet out the protein demand of $75.0,43.2$ and $41.6 \%$ 
more adults equivalent to 33,19 and 18 more persons ha $^{-1}$ year ${ }^{-1}$ as compared to Sc1 (Fig. 3). CA-based scenarios with mungbean could meet out the adult protein demand of 1-8 persons ha $^{-1}$ year ${ }^{-1}$ more compared to without mungbean integration. Rice based systems could meet out the adult protein demand by 7.5\% (3 persons $\mathrm{ha}^{-1} \mathrm{yr}^{-1}$ ) compared to Sc1. System adult

sprote $\in$, carbohydrate and fatdem and swerefoundsign if icantly $(p \leq 0.05) \in$ fluencedbyd $\Leftrightarrow$ erentcrops and theirmana $\geq$ mentpractic

s carbohydrate demand generally followed the trend observed for carbohydrate yield. Among all scenarios, Sc5 could meet out the highest adult carbohydrate demand of 109 persons ha ${ }^{-1}$ year ${ }^{-1}$ compared to 86 persons ha ${ }^{-1}$ year ${ }^{-1}$ with Sc1 (2 years mean).Sc5, Sc2 and Sc3 could meet out the carbohydrate demand by 26.7, 4.7 and 2.3\% more adults compared to Sc1, respectively. Among the CA-based scenarios, Sc4 could meet out the highest adult fat demand of 118 persons ha- ${ }^{-1}$ year ${ }^{-1}$ compared to 12 persons ha ${ }^{-1}$ year ${ }^{-1}$ with Sc1 (2 years' mean). Sc6 and Sc5 were also able to meet out the adult fat demand of 49 and 33 more persons ha-1 year-1 $^{-1}$ compared to Sc1 (Fig. 3).

Economic nutrient efficiency. The 2 years results showed that system level economic-efficiency of protein, carbohydrate and fat varied from 1.68-2.68, 0.260.53 and 2.72-18.71 USD kg-1 , respectively, under different scenarios (Fig. 3). In term of economic efficiency of protein, Sc6 was found the most efficient (29.0\% higher than Sc1) economic scenario among the all scenarios, and was able to produce $1 \mathrm{~kg}$ protein from 1.68 USD compared to 2.37 USD with Sc1.Sc1 required $40.9 \%$ higher money to produce the same protein yield as was with Sc6 $\left(1.68 \mathrm{USD} \mathrm{kg}{ }^{-1}\right)$. Rest of the scenarios required more money to produce the protein as compared to Sc1. Rice based CA scenarios (Sc2 and Sc3) required almost similar amount to get one unit of carbohydrate compared to Sc1. While other maize (Sc4 and Sc5), soybean (Sc6) and pigeon pea (Sc7) based systems required 56.3, 105.8 and $92.2 \%$, respectively, more money to produce carbohydrate similar to Sc1 (Fig. 3). In terms of fat efficiency Sc4, Sc5 and Sc6 were found as the most efficient systems and reduced the income by83.1, 56.3, $74.8 \%$, respectively, to get one unit of fat compared to Sc1 $\left(16.05 \mathrm{USD} \mathrm{kg}^{-1}\right)$.

\section{Discussion}

Crop productivity. Diversification of conventional tillage (CT)-based rice-wheat (RW) system with other remunerative crops like maize and mustard with CAbased management practices improved the systems' productivity. The rice grain yield and its system equivalent (Rice Equivalent; RE) was not much affected with different tillage (CT vs ZT) and crop establishment (transplanted and DSR) method in the present study period. These results are in close conformity with the earlier workers ${ }^{1,2,18}$. Maize yield (RE) under CA-based scenarios (Sc4-Sc5) were significantly $(\mathrm{P} \leq 0.05)$ higher by $26-32 \%$ than the other scenarios. Higher maize yields on PBs might be due to the compound effects of better crop establishment method, optimum plant density, better water regimes ${ }^{1,20}$, less biotic and abiotic stress, active soil aeration, lesser weed population, improved soil physical health ${ }^{20,21}$ and improved nutrient use efficiency ${ }^{9}$ compared to CT-based systems. Furthermore, CA-based permanent beds moderate soil temperature and moisture creating favourable conditions by residue mulch and efficient use of irrigation water and nutrients ${ }^{1,22}$. In both the kharif seasons, PBs also reduced climatic risks from, excess rainfall, dry spell, less crops logging and lodging, resulting in luxury crop growth of soybean, pigeon pea, mustard, mungbean and maize.

Higher (0.9-11.3\%) wheat yields under ZT-based scenarios (Sc2-Sc7) are likely due to the implementation of portfolios of CSA practices in the right time (early sowing) right method (zero tillage), right amount (fertilizer and water) at right place (crop root zone), which brought a negative effect on weed population and a positive one on soil physico-chemical and biological properties ${ }^{22,23}$. In the IGP region, many researchers showed that growing rice without puddling (with aerobic methods) has positive effects on the next succeeding crops by avoiding soil compaction ${ }^{2,24,25}$. In the Western IGP, zero tillage offers early wheat seeding by about 2 weeks which along with residue mulch is attributable to better temperature modulation and crop protection from heat stress during wheat reproductive stage ${ }^{26}$. The present findings of higher wheat yield under PB planting in second year could be due to the compound effects of portfolios of CSA practices. In wheat and mustard, crop residue mulch in PBs provides favourable conditions for crop growth and yields and this is consistent with earlier observations $^{22,27}$.

The highest system grain yield in Sc4 and Sc5 was because of the combined effect of system 's higher yield supplemented with additional yield from summer mungbean ${ }^{18,24}$. Higher system yield on PBs was mainly due to residue mulch and efficient use of limited water during the dry season (summer and winter) and drainage of excess water during the rainy season leading to higher productivity of crops in the respective season. The productivity CT-based RW system was poor mainly due to poor performance of both the crops ${ }^{20,23}$. However, under CA-based systems, pigeon pea-wheat system was poor mainly due to poor performance of pigeon pea crop (Table 1).

Crop profitability. Lower production cost and higher crop yields gained in CA-based systems compared with CT-based systems contributed towards the higher net returns (Table 1) in all the scenarios during both the years. Consistent with our earlier studies in the same ecology $7,18,23$, we found that the adoption of $\mathrm{ZT}$ reduced the production cost by $79-85 \%$ compared to conventional tillage (CT) and manual transplanting (in rice)/broadcasting (in wheat). Under PBs, the higher net income was due to less cost of cultivation in tillage and irrigation and higher grain yield of crops. Mungbean integration in maize-mustard and pigeon pea-wheat improved the net returns by $30 \%$ compared to other cropping systems. This crop provides a better window for mungbean cultivation ${ }^{22}$. Higher net return under maize, soybean and pigeon pea based systems under CA-based management system was due to cumulative effect of higher or at par yields, less cost of cultivation (in tillage, irrigation and fertilizer), and higher minimum support price (MSP). In PBs, lesser water and labour demand reduced the input costs to a greater extent compared to maize based CT scenarios ${ }^{15}{ }^{22}$. Sustainable intensification of the CA-based MW system through mungbean integration maximized the net income, which was higher by USD $451 \mathrm{ha}^{-1}$ compared to CT-based scenario (Sc1) and was mainly due to additional income generated from mungbean (Table 1). Our findings are consistent with the earlier studies by Jat et al. ${ }^{22}$ and Pooniya et al. ${ }^{28}$ who also registered higher net returns with PBs compared to flat system. 
Irrigation water use and water productivity. Diversification of conventional tillage (CT)-based rice-wheat (RW) system with other remunerative crops like maize, soybean, pigeon pea and mustard with CA-based management practices saved the systems' irrigation water use and improved the water productivity (Fig. 2). The lower irrigation water use in direct seeded rice (DSR) scenarios (Sc2-Sc3) was mainly due to avoidance of puddling which requires water equivalents to 34 irrigations and in combination with crop residues retention that probably minimized the evaporation loss from the soil surface ${ }^{2,25}$. Replacement of rice from the rice-wheat system using other crops like maize, soybean, pigeon pea required only $5-10 \%$ of total irrigation water used by the rice-wheat system. This might be due to the lower water requirement of these crops. Diversified systems layered with water smart (furrow irrigation, tensiometer based irrigation, use of ICTs for precise weather information) and carbon smart (reside retention, zero-tillage, mungbean integration) agricultural practices resulted in more lower water use and higher water productivity compared to the traditional method of irrigation (border irrigation based on crop morphology). These results are in close conformity with those reported by Jat et al. ${ }^{18,22}$ and Pooniya et $a l^{28}$ under different cropping systems. In wheat and mustard, PBs reduced irrigation water by 33\% (2-years' mean) compared to Sc1 (Fig. 2). The highest irrigation water productivity (WP $)$ was recorded with CA-based maize-mustard-

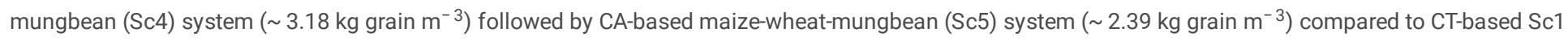
$\left(0.54 \mathrm{~kg}_{\text {grain }} \mathrm{m}^{-3}\right)$. This was mainly due to less irrigation water used coupled with higher grain yields of respective crops under the different cropping system. Similar results of higher $\mathrm{WP}_{1}$ in CA-based Sc4 and Sc5 in the IGP of India were also recorded by many researchers ${ }^{1,18}$. Higher values of WP, in the MW system on PBs compared to flat planting were also reported by Jat et al. ${ }^{27}$.

Protein yield and adult demand equivalent. Presently, RW system in the western IGP is facing challenges of exaggerating decline in input use efficiencies and, soil and environmental quality. Therefore, diversification of cereal crops with pulses and oilseeds is required to achieve the nutritional security in the region ${ }^{29}$. CA-based crop diversification in this study showed a potential to combat the identical challenges of declining value of natural resources and import of protein and fat (oil and pulses). Crop diversification provides a diversity of diet (protein, carbohydrate and fat) and improves their yield, income and nutritional security (Table 2). Higher protein yield was recorded in all the scenarios where pulse crops (soybean, pigeon pea and mungbean) were included in the system. Soybean based CA scenario (Sc6) produced higher protein yield because soybean and mungbean contain 40-42 and 20-25\% protein, respectively, that resulted in higher protein yield ${ }^{30}$. Higher protein yield with mungbean integration in RW system was also reported by Jat et al. ${ }^{18}$ and Parihar et al. ${ }^{15}$. CA-based management systems improved the protein yield by providing window for mungbean cultivation in between wheat harvest and rice sowing compared to $\mathrm{CT}$

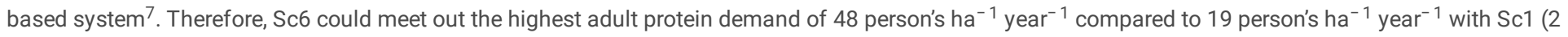
years mean). This was mainly due to high protein (40-42\%) and oil content (20-22\%) as well as more yield with best management practices, soybeans crop is among the best sources of plant-based protein ${ }^{31}$. Therefore, this is considered to be an important food product for reducing malnutrition in Indian people $\mathrm{s}^{32}$. Maize based scenarios (Sc4 and Sc5) also produced the higher protein yield because mustard and mungbean grain contain 30-35 and 20-50\% protein on dry matter basis, respectively. Therefore, these scenarios could meet the adult protein demand of 16 and $^{19}$ person's ha $^{-1}$ year ${ }^{-1}$ extra compared to farmers' practice (Sc1). Additionally, crop residue retention and biological $\mathrm{N}$-fixation by legume crops grown in the CA-based systems; favourably affect soil physicochemical and biological properties resulting in positive impact on protein yield over the years ${ }^{29}$. The Sc4 was more economically efficient in terms of protein because it contained lower protein content and higher net returns as compared to CT based RW system.

Carbohydrate yield and adult demand equivalent. Carbohydrate yield was influenced by the crop yields and their carbohydrate content in the grains. The carbohydrate content varies from $70-78 \%$ in rice, maize and wheat and influenced to some extent by the management practices ${ }^{33}$. However, in pulses and oilseeds, the carbohydrate is almost half of the content found in cereal crops and varies from $30-40 \%$ only. Maize based scenario (Sc5) produced highest carbohydrate yield compared to all other scenarios. The highest carbohydrate yield was associated with the higher grain yield of the maize and wheat crop in the respective scenarios, as, maize grains contain $75-78 \%$ and wheat70-73\% carbohydrate ${ }^{30}$. The higher carbohydrate yield under CA-based maize-wheatmungbean system could be associated with higher grain yield and supplemented with the commendatory soil temperature/moisture conditions, improved soil properties, better water and nutrient uses besides, amalgamating the effects of the residue retention ${ }^{15}$. Application of best crop management practices improved the nutritional quality of the crops by increasing the availability of nutrients from the surface layer under CA-based cropping systems ${ }^{9}$. Higher

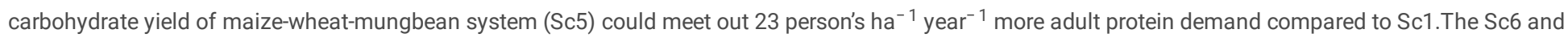
Sc7 were more economically efficient in terms of carbohydrate because it contained lower carbohydrate content and higher net returns as compared to CT based RW system.

Fat yield and adult demand equivalent. Fat yield of different cropping systems is proportional to fat content in the grains and the crop yields. Highest fat yield was recorded with Sc4 (maize-mustard-mungbean) followed by Sc6 (soybean-wheat-mungbean) and Sc5 (maize-wheat-mungbean). Higher yield with Sc4 was owing to integration of mustard instead of wheat that contained higher fat percentage (28-32\%). Soybean contained $18-20 \%$ fat content that resulted in second highest fat yield ${ }^{30}$. In maize, rice and wheat fat content is 4-5, 0.5-1 and 1-2\%, respectively, which is very low, compared to oilseeds (mustard and soybean) ${ }^{34}$. Additional fat yield under CA-based Sc4, Sc6 and Sc5 could meet the adult fat demand of 99, 32 and 49 person's ha- $^{-1}$ year ${ }^{-1}$, respectively, compared to 13 persons ha $^{-1}$ year $^{-1}$ with Sc1. This might be due to the higher fat content in the respective crops. The Sc2, Sc3 and Sc7 were more economically efficient in terms of fat because it contained lower fat content and higher net returns as compared to CT based RW system.

\section{Conclusion}

Agroecological approaches such as Conservation Agriculture (CA)-based cropping system diversification might help addressing the critical issues in farming and increase farm income while ensuring sustainable and healthy food and ecological security in developing countries including India. Our study demonstrated that diversified cropping systems with CA-based management increased the system productivity (+ 16\%), profitability (+ $27 \%)$ and protein yield (+30\%) compared to CT-based rice-wheat system. Maize-wheat-mungbean on permanent beds was found as the most efficient production system, which resulted in $32.3 \%$ more grains, $57.4 \%$ higher economic profitability along with $43.8,27.5$ and $259.8 \%$ higher protein, carbohydrate and fat yields, respectively, 
compared to farmers' business as usual practice (CT- based RW system). Our study, therefore, demonstrated that, CA-based, maize-mustard-mungbean, maizewheat-mungbean and soybean-wheat-mungbean rotation has a potential to combat the identical challenges of -deteriorating natural resources and import dependence for protein and fat in the form of oil and pulses for nutritional security. Crop diversification and sustainable intensification options ensure the food security and improve the quality of life by enriching food with balanced nutrition.

\section{Method And Materials}

Experimental site characteristics. The present study was carried out for 2 years (2018-2020) at experimental farm of ICAR-Central Soil Salinity Research Institute, Karnal $\left(29^{\circ} 42 \rrbracket 20.7 \otimes N\right.$ latitude, $76^{\circ} 57 \rrbracket 19.79 \otimes \mathrm{E}$ longitude). The region has a semi-arid condition with sub-tropical climate characterized by wet summers and dry winters and having three distinct seasons i.e. kharif (July-Oct), rabi (Nov-Mar) and zaid (April-June). The cyclonic rains are received through south-west monsoon and the region receives an average annual rainfall of $670 \mathrm{~mm}, 70-80 \%$ of which occurs from June to Sep (monsoon season). The soil of the experimental field was silty loam in texture, low in organic carbon $(0.48 \%)$ with slightly alkaline $\mathrm{pH}(8.13)$.

Experimental details and description of scenarios. In this study, a portfolio of management practices has been evaluated under different crops and cropping systems (Fig. 4). Seven combination of treatments with different crop rotations and associated management practices referred as scenarios (Sc) were evaluated as per the prevailing condition in the western Indo-Gangetic plains. Seven scenarios with the layering of different agronomic management practices were as follows: Sc1 (FP; farmers' practice)-puddled transplanted rice (PTR) followed by (fb) conventional tillage (CT) wheat without residue(-R); Sc2-CT direct seeded rice (CTDSR) fb zero tillage wheat (ZTW) with residue(+ R); Sc3- ZTDSR fb ZTW fb ZT mungbean(+ R); Sc4-ZT raised beds (PBs; permanent beds) based maize-mustard-mungbean system(+ R); Sc5-maize-wheat-mungbeansystem on PBs (+ R); Sc6- soybean-wheat-mungbean system on PBs (+ R); Sc7pigeon pea-wheat-mungbean system on PBs $(+\mathrm{R})$ were tested and evaluated for productivity, profitability and nutrition. Each scenario was replicated thrice in a production scale plot $\left(12 \mathrm{~m} \times 50 \mathrm{~m}=600 \mathrm{~m}^{2}\right)$ in a randomized complete block design. All the management practices in Sc1 was as per the current farmers' practice in the region, whereas Sc2, Sc3, Sc4, Sc5, Sc6 and Sc7 were based on conservation agriculture (CA) based management practices. The description of different scenarios and their management practices are presented in Tables 4 and 5 . Handling of plants was carried out in accordance with relevant guidelines and regulations of CCSHAU, Hisar and ICAR-CSSRI, Karnal. Seeds of all different crop varieties taken in this study are commercially available in India.

Crop residue management under different scenarios. In farmers' practice (Sc1), all the crop residues were removed from each crop. In Sc2, all rice residues were retained but anchored wheat residues were incorporated before conventional-till direct seeded rice (DSR) sowing. However, in Sc3 all rice residue and anchored wheat residue were retained on the soil surface. In Sc 4, and 5, partial (60-65\%; $150 \mathrm{~cm}$ from soil surface or just above the cob) maize residues and anchored wheat stubbles (25-30\%; $15 \mathrm{~cm}$ from the surface) were retained at the soil surface. In Sc 6 and 7, soybean ( 25-30\%) and pigeon pea ( 20$25 \%$ residues and anchored wheat residue were retained on soil. All mungbean residues were retained at the soil surface in respective scenarios.

Fertilizer and weed management. Protocols related to fertilizer management in each crops under different scenario are presented in Table 5. All the crops were fertilized with recommended dose of fertilizers (RDF) over both the years. From Sc1 to Sc3, $25 \mathrm{~kg} \mathrm{ZnSO}_{4}$ ha $^{-1}$ was applied to rice crop only. Whole P, K and Zn were applied as basal at sowing/transplanting time, while remaining $\mathrm{N}$ was top dressed as urea in two to three equal splits depending on the sensitive stages of crops. Full dose of NPK was applied at the time of sowing in leguminous crops (soybean, pigeon pea, and mungbean).

A pre-plant application of glyphosate $1.25 \mathrm{I}$ a.i. per hectare was applied to manage the weeds in permanent beds and zero-till plots. The weeds in the experimental plots were controlled through pre-emergence and post-emergence herbicides as per the standard recommendation. The herbicides used for weed control in DSR (CT/ZT) were: pendimethalin $\left(1000 \mathrm{~g}\right.$ a.i. ha $\left.{ }^{-1}\right)$ as pre-emergence followed by Bispyribac Sodium + Pyrazosulfuron ethly $\left(8-10 \mathrm{~g}+6 \mathrm{~g}\right.$ a.i. ha ${ }^{-1}$, respectively) at 20-25 days after sowing (DAS) to control all grassy and broad leaf weeds and sedges. In maize, atrazine (1000 g a.i. ha-1) followed by Laudis ${ }^{\circledR}$ Tembotrione $42 \%$ SC ( $90 \mathrm{~g}$ a.i. ha ${ }^{-1}$ ) were used as pre- and post-emergence herbicides depending on the intensity and diversity of weed species, respectively. In soybean and pigeon pea, pre- (2 DAS) and post- emergence (40 DAS) of pendimethalin (1500 ml ha-1) or post-emergence spray of Imazethapyr and Quizalofop ethyl (750 $\left.\mathrm{ml} \mathrm{ha}^{-1}\right)$ was applied at $15-20 \mathrm{DAS}$, respectively. In wheat, tank mix solution of Pinoxaden $5 \% \mathrm{EC}\left(50 \mathrm{~g}\right.$ a.i. ha- $\left.{ }^{-1}\right)$ or 
Table 4

Crop rotation, tillage and crop establishment method, residue management and water management protocols under different scenarios

\begin{tabular}{|c|c|c|c|c|c|}
\hline Scenarios & Crop rotations & Tillage & Crop establishment method & Residue management & $\begin{array}{l}\text { Water } \\
\text { managemen }\end{array}$ \\
\hline \multirow[t]{2}{*}{ Sc1 } & $\begin{array}{l}\text { Rice-wheat- } \\
\text { fallow }\end{array}$ & CT-CT & $\begin{array}{l}\text { Rice: Puddled transplanted } \\
\text { rice with random geometry }\end{array}$ & All crop residues removed & $\begin{array}{l}\text { Border } \\
\text { irrigation }\end{array}$ \\
\hline & & & $\begin{array}{l}\text { Wheat: Conventional till } \\
\text { (CT) with broadcast seeding }\end{array}$ & & \\
\hline \multirow[t]{2}{*}{ Sc2 } & $\begin{array}{l}\text { Rice-wheat- } \\
\text { fallow }\end{array}$ & CT-ZT & $\begin{array}{l}\text { Rice: CT direct seeded rice } \\
\text { (DSR) with row geometry }\end{array}$ & $\begin{array}{l}\text { Full }(100 \%) \text { rice residue retained and anchored } \\
(25-30 \%) \text { wheat residue incorporated }\end{array}$ & Same as Sc1 \\
\hline & & & $\begin{array}{l}\text { Wheat: Zero tillage (ZT) } \\
\text { wheat with row geometry }\end{array}$ & & \\
\hline Sc3 & $\begin{array}{l}\text { Rice-wheat- } \\
\text { mungbean }\end{array}$ & $\begin{array}{l}\text { ZT-ZT-ZT under } \\
\text { flats }\end{array}$ & $\begin{array}{l}\text { All crops under ZT with row } \\
\text { geometry }\end{array}$ & $\begin{array}{l}\text { Full rice and mungbean, and anchored wheat } \\
\text { residue retained }\end{array}$ & Same as Sc1 \\
\hline Sc4 & $\begin{array}{l}\text { Maize- } \\
\text { mustard- } \\
\text { mungbean }\end{array}$ & $\begin{array}{l}\text { ZT-ZT-ZT under } \\
\text { permanent beds } \\
\text { (PBs) }\end{array}$ & Same as Sc3 & $\begin{array}{l}\text { Anchored residue of maize }(60-70 \%) \text { and mustard } \\
(30-40 \%) \text {, and full mungbean residue retained }\end{array}$ & $\begin{array}{l}\text { Furrow } \\
\text { irrigation }\end{array}$ \\
\hline $\operatorname{Sc5}$ & $\begin{array}{l}\text { Maize-wheat- } \\
\text { mungbean }\end{array}$ & Same as Sc4 & Same as Sc3 & $\begin{array}{l}\text { Anchored residue of maize, and wheat, and full } \\
\text { mungbean residue retained }\end{array}$ & Same as Sc4 \\
\hline Sc6 & $\begin{array}{l}\text { Soybean- } \\
\text { wheat- } \\
\text { mungbean }\end{array}$ & Same as Sc4 & Same as Sc3 & $\begin{array}{l}\text { Anchored residue of soybean }(25-30 \%) \text {, wheat and } \\
\text { full mungbean residue retained }\end{array}$ & Same as Sc4 \\
\hline Sc7 & $\begin{array}{l}\text { Pigeon pea- } \\
\text { wheat- } \\
\text { mungbean }\end{array}$ & Same as Sc4 & Same as Sc3 & $\begin{array}{l}\text { Anchored residue of pigeon pea (20-25\%), wheat } \\
\text { and full mungbean residue retained }\end{array}$ & Same as Sc4 \\
\hline
\end{tabular}


Table 5

Crop management practices for crops and cropping systems under different management scenarios

\begin{tabular}{|c|c|c|c|c|c|c|c|}
\hline $\begin{array}{l}\text { Scenarios }{ }^{a} / \\
\text { Management } \\
\text { practices }\end{array}$ & Scenario 1 & Scenario 2 & Scenario 3 & Scenario 4 & Scenario 5 & Scenario 6 & Scenario 7 \\
\hline \multirow[t]{2}{*}{$\begin{array}{l}\text { Field } \\
\text { preparation }\end{array}$} & $\begin{array}{l}\text { Rice- } 2 \text { pass of harrow, } 1 \text { pass of } \\
\text { rotavator, } 2 \text { pass of puddle harrow } \\
\text { followed by (fb) planking }\end{array}$ & $\begin{array}{l}\text { Rice- } 1 \text { pass of harrow, } 1 \\
\text { pass of cultivator } \mathrm{fb} \\
\text { planking }\end{array}$ & \multirow[t]{2}{*}{$\begin{array}{l}\text { Zero tillage } \\
\text { (ZT) on } \\
\text { flats }\end{array}$} & \multirow[t]{2}{*}{$\begin{array}{l}\text { ZT on } \\
\text { permanent } \\
\text { beds }(\mathrm{Pbs})\end{array}$} & \multirow[t]{2}{*}{$\begin{array}{l}\text { ZT on } \\
\text { permanent } \\
\text { beds }(\mathrm{Pbs})\end{array}$} & \multirow[t]{2}{*}{$\begin{array}{l}\text { ZT on } \\
\text { permanent } \\
\text { beds }(\mathrm{Pbs})\end{array}$} & \multirow[t]{2}{*}{$\begin{array}{l}\text { ZT on } \\
\text { permanent } \\
\text { beds }(\mathrm{Pbs})\end{array}$} \\
\hline & $\begin{array}{l}\text { Wheat- } 2 \text { pass of harrow and } \\
\text { rotavator each fb planking }\end{array}$ & Wheat- Zero tillage & & & & & \\
\hline \multirow{3}{*}{$\begin{array}{l}\text { Seed rate }(\mathrm{kg} \\
\left.\mathrm{ha}^{-1}\right)\end{array}$} & Rice- 12.5 & Rice- 20 & Rice- 20 & Maize- 20 & Maize- 20 & $\begin{array}{l}\text { Soybean- } \\
20\end{array}$ & $\begin{array}{l}\text { Pigeon } \\
\text { pea- } 15\end{array}$ \\
\hline & \multirow[t]{2}{*}{ Wheat- 100} & \multirow[t]{2}{*}{ Wheat- 100} & Wheat-100 & & Wheat- 100 & Wheat- 100 & \multirow{2}{*}{$\begin{array}{l}\text { Wheat- } 100 \\
\text { Mungbean- } \\
20\end{array}$} \\
\hline & & & $\begin{array}{l}\text { Mungbean- } \\
20\end{array}$ & $\begin{array}{l}\text { Mungbean- } \\
20\end{array}$ & $\begin{array}{l}\text { Mungbean- } \\
20\end{array}$ & $\begin{array}{l}\text { Mungbean- } \\
20\end{array}$ & \\
\hline $\begin{array}{l}\text { Sowing } \\
\text { method }\end{array}$ & $\begin{array}{l}\text { Manual transplanting of rice and } \\
\text { broadcasting of wheat }\end{array}$ & $\begin{array}{l}\text { Rice seeding with multi- } \\
\text { crop planter and wheat } \\
\text { seeding with Happy } \\
\text { Seeder machine }\end{array}$ & $\begin{array}{l}\text { Seeding } \\
\text { with Happy } \\
\text { Seeder } \\
\text { machine }\end{array}$ & $\begin{array}{l}\text { Seeding } \\
\text { with } \\
\text { double } \\
\text { disc } \\
\text { planter }\end{array}$ & $\begin{array}{l}\text { Seeding } \\
\text { with } \\
\text { double } \\
\text { disc } \\
\text { planter }\end{array}$ & $\begin{array}{l}\text { Seeding } \\
\text { with } \\
\text { double } \\
\text { disc } \\
\text { planter }\end{array}$ & $\begin{array}{l}\text { Seeding } \\
\text { with } \\
\text { double } \\
\text { disc } \\
\text { planter }\end{array}$ \\
\hline $\begin{array}{l}\text { Crop } \\
\text { geometry } \\
(\mathrm{cm})\end{array}$ & Random geometry & $22.5-22.5$ & $\begin{array}{l}22.5^{-} \\
22.5^{-45}\end{array}$ & $\begin{array}{l}67.5- \\
33.7-33.7\end{array}$ & $\begin{array}{l}\text { 67.5- } \\
33.7-33.7\end{array}$ & $\begin{array}{l}33.7- \\
33.7-33.7\end{array}$ & $\begin{array}{l}67.5- \\
33.7-33.7\end{array}$ \\
\hline \multirow{4}{*}{$\begin{array}{l}\text { Fertilizers } \\
(\mathrm{N}: \mathrm{P}: \mathrm{K}) \text { in } \mathrm{kg} \\
\mathrm{ha}^{-1}\end{array}$} & \multirow{4}{*}{$\begin{array}{l}\text { Rice- 195:57.5:00 } \\
\text { Wheat- 166:57.5:00 } \\
\text { ZnSO }_{4} @ 25 \text { kg ha }^{-1}\end{array}$} & \multirow{4}{*}{$\begin{array}{l}\text { Rice- 150:60:60 } \\
\text { Wheat- 150:60:60; } \mathrm{ZnSO}_{4} \\
\text { @25 kg ha-1 }\end{array}$} & \multirow{3}{*}{$\begin{array}{l}\text { Rice- } \\
\text { 150:60:60 } \\
\\
\mathrm{ZnSO}_{4} \\
@_{2} 25 \mathrm{~kg} \\
\mathrm{ha}^{-1}\end{array}$} & $\begin{array}{l}\text { Maize- } \\
\text { 150:60:60 }\end{array}$ & $\begin{array}{l}\text { Maize- } \\
\text { 150:60:60 }\end{array}$ & \multirow{2}{*}{$\begin{array}{l}\text { Soybean- } \\
25: 80: 00\end{array}$} & \multirow{2}{*}{$\begin{array}{l}\text { Pigeon } \\
\text { pea- } \\
\text { 20:40:00 }\end{array}$} \\
\hline & & & & \multirow{2}{*}{$\begin{array}{l}\text { Mustard- } \\
80: 30: 20\end{array}$} & \multirow{2}{*}{$\begin{array}{l}\text { Wheat- } \\
150: 60: 60\end{array}$} & & \\
\hline & & & & & & $\begin{array}{l}\text { Wheat- } \\
\text { 150:60:60 }\end{array}$ & $\begin{array}{l}\text { Wheat- } \\
\text { 150:60:60 }\end{array}$ \\
\hline & & & $\begin{array}{l}\text { Wheat- } \\
\text { 150:60:60 } \\
\text { Mungbean- } \\
\text { 20:40:00 }\end{array}$ & $\begin{array}{l}\text { Mungbean- } \\
20: 40: 00\end{array}$ & $\begin{array}{l}\text { Mungbean- } \\
20: 40: 00\end{array}$ & $\begin{array}{l}\text { Mungbean- } \\
20: 40: 00\end{array}$ & $\begin{array}{l}\text { Mungbean- } \\
20: 40: 00\end{array}$ \\
\hline \multirow{3}{*}{$\begin{array}{l}\text { Water } \\
\text { management } \\
\text { (no. of } \\
\text { irrigations) }\end{array}$} & \multirow{2}{*}{$\begin{array}{l}\text { Rice- Continuous flooding of } 5-6 \\
\mathrm{~cm} \text { depth for } 50-60 \text { days after } \\
\text { transplanting fb irrigation applied } \\
\text { at alternate wetting and drying } \\
\text { ( } 30-35 \text { irrigations). }\end{array}$} & \multirow{2}{*}{$\begin{array}{l}\text { Rice- Soil was kept wet } \\
\text { up to } 20 \text { days after } \\
\text { sowing fb irrigation } \\
\text { applied at hair-line cracks } \\
\text { (30-40 irrigations). }\end{array}$} & $\begin{array}{l}\text { Same as } \\
\text { scenario } 2\end{array}$ & $\begin{array}{l}\text { Maize- } 4-5 \\
\text { irrigations }\end{array}$ & \multirow{3}{*}{$\begin{array}{l}\text { Maize- } 4-5 \\
\text { Wheat- 4- } \\
6 \\
\text { Mungbean- } \\
2-3\end{array}$} & $\begin{array}{l}\text { Soybean- } \\
2-4\end{array}$ & $\begin{array}{l}\text { Pigeon } \\
\text { pea- } 4-5\end{array}$ \\
\hline & & & $\begin{array}{l}\text { Wheat- 4- } \\
6\end{array}$ & $\begin{array}{l}\text { Mustard- } \\
4-6\end{array}$ & & $\begin{array}{l}\text { Wheat- 4- } \\
6\end{array}$ & $\begin{array}{l}\text { Wheat- 4- } \\
6\end{array}$ \\
\hline & Wheat- 4-6 & Wheat- 4-6 & $\begin{array}{l}\text { Mungbean- } \\
2-3\end{array}$ & $\begin{array}{l}\text { Mungbean- } \\
2-3\end{array}$ & & $\begin{array}{l}\text { Mungbean- } \\
2-3\end{array}$ & $\begin{array}{l}\text { Mungbean- } \\
2-3\end{array}$ \\
\hline
\end{tabular}

Clodinafop ethyl + Metsulfuron $\left(60+4 \mathrm{~g}\right.$ a.i. $\left.\mathrm{ha}^{-1}\right)$ was applied at 30-35 DAS to control all types of weeds.

Irrigation water management. A polyvinyl chloride (PVC) pipeline was installed in a $60 \mathrm{~cm}$ deep trench with an outlet for each plot separately. On-line water meter (Woltman ${ }^{\circledR}$ helical turbine) was fitted for irrigation water measurement. Water meter readings were recorded for each irrigation to calculate the amount of irrigation water applied per plot. The amount of irrigation water applied ( $\left.\mathrm{mm} \mathrm{ha}^{-1}\right)$ and water productivity for irrigation (WP $\left.)_{\mathrm{I}}\right)$ were calculated using Eqs. (13).

Volume of irrigation water (kilolitre ha $\left.{ }^{-1}\right)=\left\{\left(\right.\right.$ final water meter reading-initial water meter reading)/plot area in $\left.\mathrm{m}^{2}\right\}$ * 10000 (1)

Irrigation water $\left(\mathrm{mm} \mathrm{ha}^{-1}\right)=$ volume of irrigation water $\left(\right.$ kilolitre ha $\left.^{-1}\right) / 10(2)$

Irrigation water productivity $=$ grain yield $\left(\mathrm{kg} \mathrm{ha}^{-1}\right) /$ irrigation water used $\left(\mathrm{mm} \mathrm{ha}^{-1}\right)(3)$

In both border and furrow irrigation systems, number of irrigations varied from 2 to 6 except rice crop. Water management protocols for each scenario are presented in Table 5.

Crop yield and net returns. Rice and wheat crops were harvested and threshed either manually or using a combine harvester at a height of $30 \mathrm{~cm}$ above ground level except in Sc1, which was harvested at ground level; whereas, maize, soybean, pigeon pea and mustard crops were harvested and threshed manually. At maturity, the grain and straw yields of both wheat and rice were determined on a total area of $100 \mathrm{~m}^{2}$ by sampling from four locations of $25 \mathrm{~m}^{2}$ each. Grain and straw yields of maize, soybean, pigeon pea, mustard and mungbean were estimated by harvesting a total area of $108 \mathrm{~m}^{2}$ from each plot by sampling from four locations of $27 \mathrm{~m}^{2}$ each. For mungbean yield estimation, the entire plot was harvested and weighed. To compare the productivity of different crops and total system productivity of the different scenarios, the yield of non-rice crops (wheat, maize, soybean, pigeon pea, mustard and mungbean) was converted into rice equivalent yield (REY) $\left(\mathrm{Mg} \mathrm{ha}^{-1}\right)$ and calculated using the Eq. (4).

Rice equivalent yield $=$ grain yield of non-rice $\operatorname{crop}\left(\mathrm{Mg} \mathrm{ha}^{-1}\right)$ * $\mathrm{MSP}$ of non-rice crop $\left(\mathrm{USD} \mathrm{Mg}^{-1}\right) / \mathrm{MSP}$ of rice $\left(\mathrm{USD}^{\mathrm{Mg}}{ }^{-1}\right)(4)$ 
where, MSP is the minimum support price (Table S1); (1 USD = 70 INR).

The data on crop management inputs such as number of tillage, fuel consumption, number of irrigations, herbicide, fertilizer, seed rate, labour use, pesticide application and their costs under each treatment were recorded for each crop using a standard data recording format. All these costs were summed up to calculate the total cost of production. Cost of key inputs and outputs used for economic analysis during the different years are presented in Table S1. Gross returns were obtained as per the prevailing market prices of the commodity (grain and straw/stover) over the different years. Net returns were calculated by deducting the total cost of cultivation from the gross returns.

Analysis of nutrient quality parameters. Grain quality parameters like protein, carbohydrate and fat contents were calculated from all the crops. The protein content was calculated using the nitrogen $(\mathrm{N})$ content in grain and grain yield of individual crops. $\mathrm{N}$ content in the grain was determined as per Jackson ${ }^{35}$. $\mathrm{N}$ content in the grain varied from $1.54-1.59 \%$ in wheat, $1.06-1.09 \%$ in rice, $1.1-1.4 \%$ in maize, $5.5-5.9 \%$ in soybean, $3.2-3.4 \%$ in pigeon pea, $3.44-3.69 \%$ in mustard, and $3.61-3.69 \%$ in mungbean. Final value of the protein was calculated by multiplying the detected $\mathrm{N}$ content with a standard factor for each crop ( 5.95 for rice; 5.80 for wheat; 6.25 for maize; 5.71 for soybean; 6.25 for pigeon pea; 5.30 for mustard and 5.70 for mungbean) as given by Mariotti et al. ${ }^{36}$ Calorimetric method/phenol- sulphuric acid method was used to determine carbohydrate concentration in the grains ${ }^{37}$. The sulphuric acid causes all nonreducing sugars to be converted to reducing sugars, so that this method determines the total sugars present. Fat content in the grains was determined with the Soxtec-Avanti 2050 total fat system (Foss Co., Denmark) method ${ }^{38}$. The yield efficiency of protein, carbohydrate and fat was calculated based on the annual adult protein, carbohydrate and fat demand equivalent based on the 58,30 and $275 \mathrm{~g} \mathrm{person}^{-1} \mathrm{day}^{-1}$, respectively, as per the recommendations of the Indian council of medical research ${ }^{39}$.

Economic-efficiency (EE) of nutrients. Economic-efficiency (EE) is an index aimed at de-coupling resource use and output produce from economic activity and the economic-efficiency indicator is defined as a ratio between economic value added and a output produced (protein, carbohydrate and fat). In this paper, economic-efficiency of protein, carbohydrate and fat yield was calculated using the Eqs. (5-7)

Economic efficiency of protein (USD/kg) = economic return (USD/ha)/ protein yield (kg/ha) (5)

Economic efficiency of carbohydrate (USD/kg) = economic return (USD/ha)/ carbohydrate yield (kg/ha) (6)

Economic efficiency of fat (USD/kg) = economic return (USD/ha) / fat yield $(\mathrm{kg} / \mathrm{ha})(7)$

Statistical analysis. The data recorded for different crop parameters were analysed using analysis of variance (ANOVA) technique ${ }^{40}$ for randomized block design using SAS 9.1 software ${ }^{41}$. The treatment means were compared using Turkey's honestly significant difference (HSD at $5 \%$ level of significance).

\section{Declarations}

It is hereby declared that all the authors have no Declarations of interest.

\section{Acknowledgments}

The authors acknowledge the support received from the ICAR-CSSRI, Karnal, and CIMMYT Academy. The research was financed and supported from CGIAR Research Program (CRPs) on Climate Change, Agriculture and Food Security (CCAFS), Wheat Agri-Food Systems (WHEAT) and Indian Council of Agricultural Research (ICAR) W3 grant to CIMMYT for Conservation Agriculture. We acknowledge the CGIAR Fund council, Australia (ACIAR), Irish Aid, European Union, and International Fund for Agricultural Development, Netherlands, New Zealand, Switzerland, UK, USAID, and Thailand for funding to the CGIAR Research Program on Climate Change, Agriculture and Food Security (CCAFS).

\section{Author contributions}

M.L. and P.C. conceptualized the idea and directed the research project. M.G., S. Kumar and H.S. analyzed the idea in comparison with previous studies. M.G., S.K. and M.K. designed the experi-ment, coordinated fieldwork, implemented on-farm trials and collected data. M.G., H.S., S.K. and M.C. drafted the manuscript text. S. Kumar, H.S., A.K. and R.D. conceived the idea and revised and edited the manuscript. All authors analyzed the data, discussed the results, commented on the manu-script and reviewed the manuscript.

\section{Competing interests}

All the authors declare no potential conflict of interest.

\section{Availability of data and materials}

The datasets used and /or analysed during the current study available from the corresponding author on reasonable request

\section{References}

1. Choudhary, K. M. et al. Evaluating alternatives to rice-wheat system in western Indo-Gangetic Plains: Crop yields, water productivity and economic profitability. Field Crop Res. 218, 1-10 (2018a).

2. Kumar, V. et al. Can productivity and profitability be enhanced in intensively managed cereal systems while reducing the environmental footprint of production? Assessing sustainable intensification options in the breadbasket of India. Agric. Ecosyst. Environ. 252, 132-147 (2018).

Page 12/16 
3. Jat, M.L. et al. Conservation agriculture for sustainable intensification in South Asia. Nat. Sustain. 3, 336-343 (2020a).

4. Jat, M. L. et al. Climate change and agriculture: Adaptation strategies and mitigation opportunities for food security in South Asia and Latin America. Adv. Agron. 137, 127-236 (2016).

5. Humphreys, E. et al. Halting the groundwater decline in North-West India-which crop technologies will be winners?. Adv. Agron. 109, 155-217 (2010).

6. Bhattacharyya, T., Pal, D.K., Mandal, C. \& Velayutham, M. Organic carbon stock in Indian soils and their geographical distribution. Curr. Sci. 79, 655-660 (2000).

7. Jat, H.S. et al. Conservation agriculture based sustainable intensification of basmati rice-wheat system in North-West India. Arch. Agron. Soil Sci. $\mathbf{6 5}$, 1370-1386 (2019a).

8. Sharma, P.C. et al. Sustainable intensification opportunities under current and future cereal systems of North-West India. Technical Bulletin: CSSRI/Karnal/2015/4 Central Soil Salinity Research Institute, Karnal pp. 46 (2015).

9. Jat, H. S. et al. Assessing soil properties and nutrient availability under conservation agriculture practices in a reclaimed sodic soil in cereal-based systems of North-West India. Arch. Agron. Soil Sci. 64, 531-545 (2018a).

10. Choudhary, M. et al. Changes in soil biology under conservation agriculture based sustainable intensification of cereal systems in Indo-Gangetic Plains. Geoderma 313, 193-204 (2018b).

11. Yadav, G. et al. Enterprise mix diversification: an option for ecologically sustainable food and nutritional security of small holders in Indo-Gangetic plains. Int. J. Agric. Sustain. 1-11 (2021).

12. Chand, R. \& Chauhan, S. Socio-economic factors in agricultural diversification in India. Agric. Situ. India pp. 523-529 (2002).

13. Gupta, R.P. \& Tewari, S.K. Factors affecting crop diversification: A critical Analysis. Indian J. Agric. Econ. 40, 304-309 (1985).

14. Waha, K. et al. Multiple cropping systems of the world and the potential for increasing cropping intensiy. Glob. Environ. Change 64, 102131 (2020).

15. Parihar, C.M. et al. Bio-energy, water-use efficiency and economics of maize-wheat mungbean system under precision-conservation agriculture in semiarid agro-ecosystem. Energy 119, 245-256. (2017).

16. Damerau, K. et al. India has natural resource capacity to achieve nutrition security, reduce health risks and improve environmental sustainability. Nat. Food 1, 631-639 (2020).

17. Bijarniya, D. et al. Portfolios of Climate Smart Agriculture Practices in Smallholder Rice-Wheat System of Eastern Indo-Gangetic Plains-Crop Productivity, Resource Use Efficiency and Environmental Foot Prints. Agronomy 10, 1561 (2020).

18. Jat, H. S. et al. Re-designing irrigated intensive cereal systems through bundling precision agronomic innovations for transitioning towards agricultural sustainability in North-West India. Sci. Rep. 9, 1-14 (2019b).

19. Roberts, D. P. \& Mattoo, A. K. Sustainable agriculture - enhancing environmental benefits, food nutritional quality and building crop resilience to abiotic and biotic stresses. Agriculture 8, 8 (2018).

20. Jat, M.L. et al. Double no-till and permanent raised beds in maize-wheat rotation of North-Western Indo-Gangetic Plains of India: Effects on crop yields, water productivity, profitability and soil physical properties. Field Crop Res. 149, 291-299 (2013).

21. Singh, V.K. et al. Soil physical properties, yield trends and economics after five years of conservation agriculture based rice-maize system in North-Western India. Soil Till. Res. 155, 133-148 (2016).

22. Jat, H.S. et al. Designing profitable, resource use efficient and environmentally sound cereal based systems for the Western Indo-Gangetic plains. Sci. Rep. 10, 19267 (2020b).

23. Kakraliya, S. K. et al. Performance of portfolios of climate smart agriculture practices in a rice-wheat system of western Indo-Gangetic plains. Agric. Water Manag. 202, 122-133 (2018a).

24. Gathala, M. K. et al. Effect of tillage and crop establishment methods on physical properties of a medium textured soil under a seven year rice-wheat rotation. Soil Sci. Soc. Am. J. 75, 1851-1862 (2011).

25. Gathala, M. K. et al. Optimizing intensive cereal-based cropping systems addressing current and future drivers of agricultural change in the North-western Indo-Gangetic Plains of India. Agric. Ecosyst. Environ. 187, 33-46 (2014).

26. Jat, R. K. et al. Ten years of conservation agriculture in a rice-maize rotation of Eastern Gangetic Plains of India: Yield trends, water productivity and economic profitability. Field Crop Res. 232, 1-10 (2019c).

27. Jat, R. D. et al. Conservation agriculture and precision nutrient management practices in maize-wheat system: Effects on crop and water productivity and economic profitability. Field Crop Res. 222, 111-120 (2018b).

28. Pooniya, $\mathrm{V}$ et al. Six years of conservation agriculture and nutrient management in maize-mustard rotation: Impact on soil properties, system productivity and profitability. Field Crop Res. 260, 108002 (2021).

29. Kakraliya, S. K. et al. Nitrogen and legumes: a meta-analysis. In Legumes for Soil Health and Sustainable Management, pp.277-314 eds R. Meena, A. Das, G. Yadav, \& R. Lal, Springer, Singapore (2018b).

30. Singh, C. Modern techniques of raising field crops. Oxford and IBH publishing. (1983).

31. Sobko, O., Zikeli, S., Claupein, W. \& Gruber, S. Seed Yield, Seed Protein, Oil Content, and Agronomic Characteristics of Soybean (Glycine max L. Merrill) Depending on Different Seeding Systems and Cultivars in Germany. Agronomy, 10, 1020 (2020).

32. Samtiya, M., Aluko, R. E. \& Dhewa, T. Plant food anti-nutritional factors and their reduction strategies: an overview. Food Prod. Process. Nutrition 2 (2020).

33. Meherunnahar, M., Chowdhury, R.S., Hoque, M.M., Satter, M.A. \& Islam, M.F. Comparison of nutritional and functional properties of BK2 foxtail millet with rice, wheat and maize flour. Progress. Agric. 29, 186-194 (2018).

Page 13/16 
34. Moss, R., Gore, P.J. \& Murray, I.C. (1987). The influence of ingredients and processing variables on the quality and microstructure on Hokkien, Cantonese and Instant Noodles. Food Microstructure 6, 63-74.

35. Jackson, M. L. Soil Chemical Analysis, 2nd edn. Prentice Hall of India Pvt. Ltd. New Delhi pp. 498 (1973).

36. Mariotti, F., Tomé, D. \& Mirand, P. Converting Nitrogen into Protein - Beyond 6.25 and Jones' Factors. Critical Reviews in Food Science and Nutrition.

Taylor \& Francis 48, 177-184 (2008).

37. Dubois, M., Gilles, K. A., Hamilton, J. K., Rebers, P. A., \& Smith, F. Colorimetric Method for Determination of Sugars and Related Substances. Anal. Chem. 28, 350-356 (1956).

38. Wang, H.L. et al. Quantitative analysis of fat content in rice by near infrared spectroscopy technique. Cereal Chem. 83, 402-406 (2006).

39. ICMR Nutrient requirements and recommended dietary allowances for Indians. A Report of the Expert Group pp.334 (2009).

40. Gomez, K. A. \& Gomez, A. A. Statistical procedures for agricultural research 2nd edn, 180-209 (Wiley, New York, 1984).

41. SAS Institute SAS/STAT User's Guide. Version 8 - 1; SAS Inst.: Cary, NC, USA (2001).

\section{Table}

Table 3 is available in the Supplemental Files section.

\section{Figures}

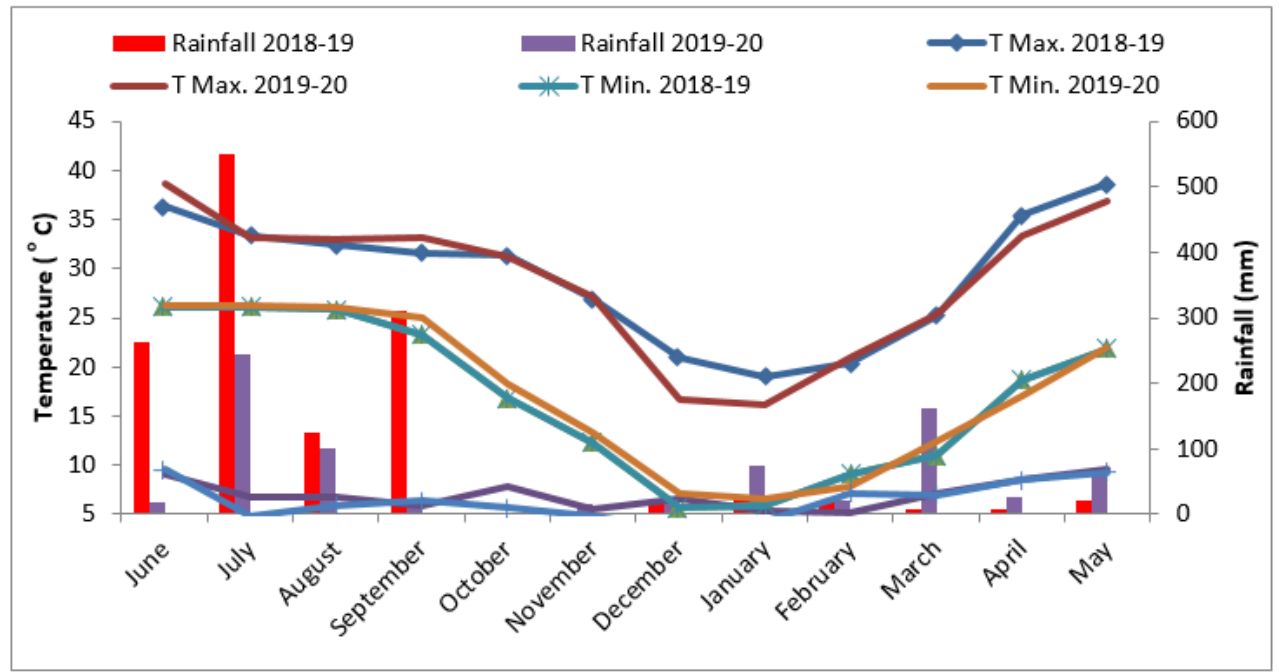

Figure 1

Yearly weather data of rainfall and temperature (max. and min.) for the year 2018-19 and 2019-20. 


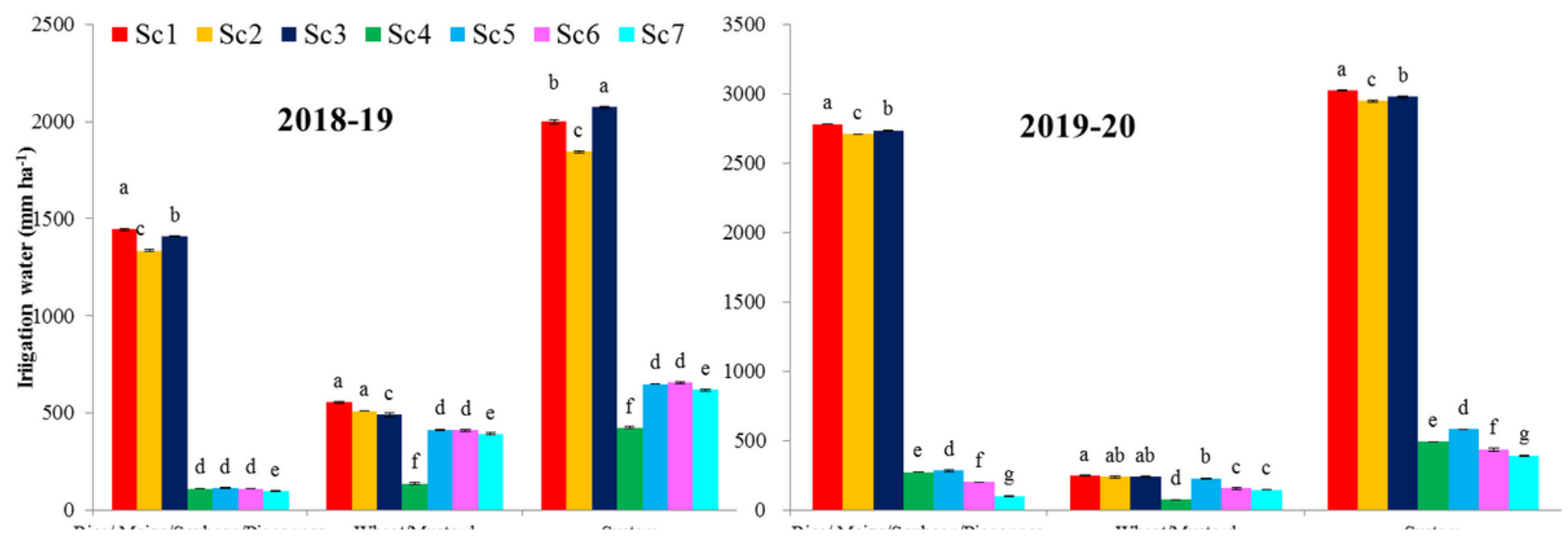

\section{Figure 2}

Irrigation water use $\left(\mathrm{mm} \mathrm{ha}^{-1}\right)$ and water productivity $\left(\mathrm{kg}_{\text {grain }} \mathrm{m}^{-3}\right)$ as affected by different cropping systems under various management scenarios $(2$ years mean) 


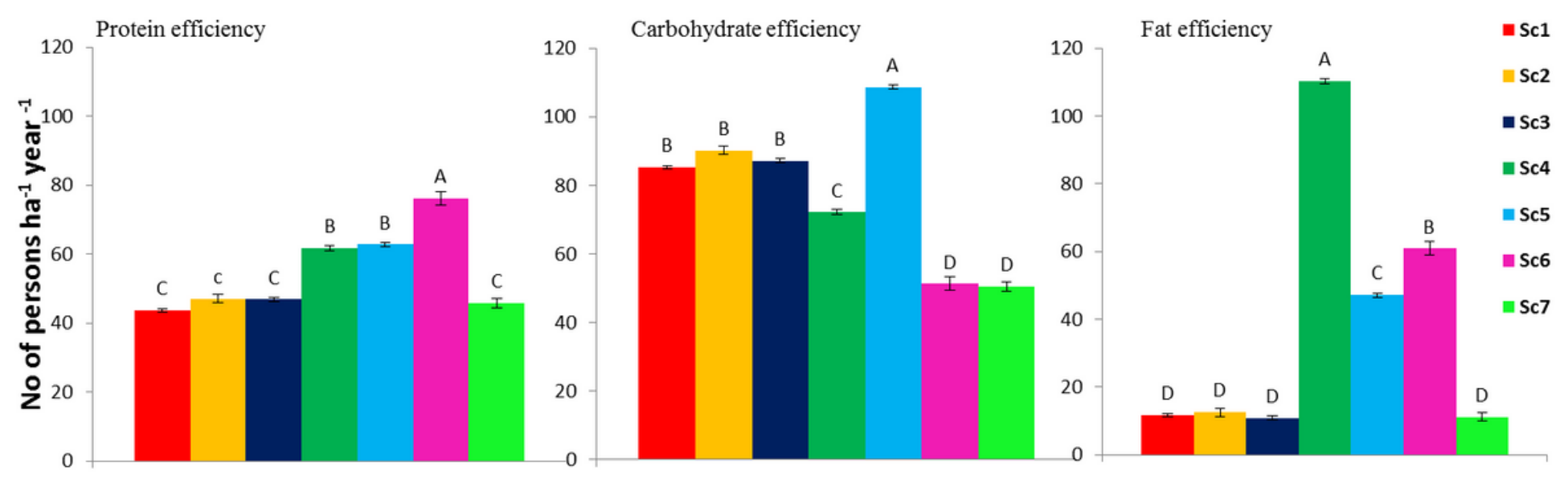

Economic efficiency of protein

nan - Eronnmir efficiency nf rarhohvidrate $25 \mathrm{nn}-$

\section{Figure 3}

Yearly protein, carbohydrate and fat demand (based on 58, 275 and $30 \mathrm{~g} \mathrm{day}^{-1}$ adult $^{-1}$ ) equivalents for adults and economic efficiency of protein, carbohydrate and fat as affected by different cropping systems under various management scenarios (2 year's mean).

\section{Figure 4}

Schematic diagram of different crops and cropping sequence under different crop establishment methods.

\section{Supplementary Files}

This is a list of supplementary files associated with this preprint. Click to download.

- Supplimentaryfile.docx

- Table3.docx 